\title{
ASSESSMENT DAN MANAJEMEN TRAUMA PADA ANAK
}

\author{
Dewi Rachmawati \\ Jurusan Keperawatan, Poltekkes Kemenkes Malang \\ Email: dewi_rachmawati@poltekkes-malang.ac.id
}

\begin{abstract}
Abstrak
Trauma adalah penyebab umum kematian dan kecacatan pada anak. Assessment dan manajemen trauma yang tepat pada anak sangat penting untuk menurunkan mortalitas. Metode literature review ini adalah mengumpulkan dan melakukan analisis textbook dan artikel yang terkait manajemen trauma pada anak. Sumber literature review dari textbook dan artikel elektronik seperti ScienceDirect, World Health Organisation, Google Scholar dan PubMed dengan kriteria textbook dan artikel yang dipublikasi selama periode 2000-2015. Assessment dan manajemen trauma pada anak prinsipnya sama dengan orang dewasa, yang membedakan karakteristik tertentu pada anak. Dimulai dari primary assessment dan resusitasi yang terdiri dari Airway dan stabilisasi tulang belakang (melihat patensi, potensial obstruksi jalan nafas dan melakukan stabilisasi tulang belakang dengan cervical collar), Breathing dan ventilasi, Circulation dan kontrol perdarahan, Disability Assessment (Pemeriksaan neurologis lengkap), Exposure dan Pemeriksaan lengkap. Sedangkan Secondary Assessment mencangkup Full set of vital sign/family presence, Give comfort, History dan Head to-toe assessment, Inspect posterior surfaces. Setelah dilakukan pengkajian dan penatalaksanaan maka langkah selanjutnya melakukan evaluasi perubahan kondisi dan memberikan tindakan perawatan yang tidak mengancam nyawa. Untuk itu perawat di unit gawat darurat harus memperhatikan dengan seksama dan melakukan pengkajian dengan tepat untuk mencegah terjadinya kematian dan pasien mendapatkan penanganan dengan segera.
\end{abstract}

Keyword: Assessment, manajemen, Trauma pada anak

\begin{abstract}
Assessment And Management Of Trauma In Pediatric. Trauma is a common cause of death and disability in children. Appropriate trauma assessment and management in children is very important to reduce mortality. This literature review method is to collect and analyze textbooks and articles related to trauma management in children. Literature review sources are textbooks and electronic articles such as ScienceDirect, World Health Organization, Google Scholar, and PubMed with the criteria of textbooks and articles published during the period 2000-2015. The principle of assessment and management of trauma in children is that of adults, which distinguishes certain characteristics in children. Starting from the primary assessment and resuscitation consisting of the airway and spinal stabilization (seeing patency, potential airway obstruction and stabilizing the spine with a cervical collar), breathing and ventilation, circulation and bleeding control, disability assessment (complete neurological examination), exposure and a complete examination. Meanwhile, the Secondary Assessment covers the Full set of vital sign/family presence, give comfort, History, and Head to toe assessment, Inspect posterior surfaces. After the assessment and management are carried out, the next step is to evaluate changes in conditions and provide non-life-threatening treatment measures. For this reason, nurses in the emergency room must pay close attention and carry out appropriate assessments to prevent death and get patients to be treated immediately.
\end{abstract}

Keyword: Assessment, management, Trauma in children 


\section{Pendahuluan}

Trauma adalah penyebab umum kematian dan kecacatan anak usia $<18$ tahun terutama di negara-negara berkembang dengan morbiditas dan mortalitas yang semakin meningkat. Anak mempunyai massa tubuh yang lebih kecil sehingga daya/tekanan pada tubuh anak lebih besar akhirnya menyebabkan adanya kecenderungan terjadi trauma (Hammond \& Zimmermann, 2013). Terdapat berbagai penyebab dari trauma anak meliputi penyebab yang disengaja (intentional injury), penyebab yang tidak disengaja (unintentional injury) dan penyebab yang tidak bisa ditentukan (undetermined intent). Penyebab tidak disengaja mempunyai prevalensi yang tertinggi mengakibatkan trauma pada anak, antara lain terjadinya kecelakaan lalu lintas/transportasi darat/laut/udara, jatuh dari ketinggian, terbakar/tersiram, luka akibat benda tajam/tumpul/mesin/ledakan, bencana alam dan cedera olahraga (Russel et al, 2004; WHO, 2004 dalam Riskesdas, 2013).

Trauma anak merupakan suatu masalah global, lebih dari 900.000 anak dan remaja di dunia meninggal karena trauma (Kristiansen et al, 2011). Setiap tahun diperkirakan 1,5 juta anak mengalami trauma, 20.000 diantaranya meninggal, 300.000 lainnya harus mendapatkan perawatan di rumah sakit dan 100.000 mengalami cacat permanen (Alterman et al, 2013; Allen et al, 2015). Trauma ini menyebabkan lebih banyak kematian pada anak-anak dan remaja dari penyebab lain (American Academy of Pediatrics and Pediatric Orthopaedic Society of North America, 2008).

Di Negara-negara berkembang trauma merupakan penyebab teratas kematian anak usia 1-14 tahun. Diperkirakan 98\% kematian anak karena trauma. Di Indonesia angka kematian pada anak akibat trauma dan merupakan salah satu lima penyebab kematian anak tertinggi. Hal ini sesuai dengan Riskesdas Departemen Kesehatan (2007) yang menyatakan 19,2\% penyebab kematian dan kecacatan anak adalah trauma yang dikuatkan data dari Mabes POLRI (2009) yang mencatat kematian akibat trauma sebesar 8.601 anak (8,8\%) (Dewi dkk, 2008)

Berdasarkan tingginya mortalitas trauma pada anak tersebut maka diperlukan assessment dan manajemen trauma yang tepat pada anak. Pada prinsipnya assessment dan manajemen trauma pada anak sama dengan pada orang dewasa, yaitu terdiri dari primary assessment, fase resusitasi, secondary assessment, reevaluasi dan monitoring setelah resusitasi serta terakhir adalah memberikan terapi definitive. Akan tetapi anak mempunyai perbedaan anatomi dan fisiologi yang signifikan dengan orang dewasa sehingga berimplikasi terhadap manajemen trauma pada anak (Hammond \& Zimmermann, 2013; Cline et al, 2013).

Oleh karena itu terdapat beberapa hal yang harus diperhatikan perawat dalam 
assessment dan manajemen trauma pada anak yaitu pertama (Airway) airway pada anak biasanya lebih kecil, lidah anak amat besar, sehingga mudah tersumbat/obstruksi. Kedua (Breathing) Pada anak-anak rasio oxygen consumption lebih banyak sehingga beresiko terjadi kerusakan pernafasan. Ketiga (Circulation) Anak beresiko kehilangan darah 25\%-30\% TBV saat terjadi trauma yang berimplikasi terjadi penurunan $\mathrm{CO}$ dan resiko syok. Keempat (Disability) Anak mempunyai porsi kepala lebih besar, sedikit myelinasi otak, tulang cranium yang lebih tipis mudah terjadinya cedera kepala berat dan peningkatan TIK pada anak. Kelima (Exposure) Anak mempunyai permukaan tubuh yang luas dibandingkan beratnya sehingga hipotermia. Keenam (Head to toe examination) Anak mempunyai BMI yang lebih rendah, ukuran tubuh yang lebih kecil, sedikit lemak sehingga jika terdapat benturan menyebabkan multipel trauma yang berat. Dan terakhir tulang kartilago thorax pada anak masih immature, dinding abdomen masih lentur serta tidak adekuatnya dinding dada menyebabkan sering terjadi trauma tumpul abdomen (Murray \& Cordle, 2015; Orlando Health Education \& Development, 2011; Schvartsman et al, 2005; Cline et al, 2012; Bakes \& Sharieff, 2013).

Dengan demikian, untuk memudahkan perawat maka akan dibahas lebih detail mengenai bagaimana seharusnya penanganan atau manajemen yang tepat pada anak dengan trauma.

\section{Metode}

Penelitian ini berjenis literature review yang menganalisis assessment dan manajemen trauma pada anak di instalasi gawat darurat. Variabel independen adalah assessment dan manajemen trauma pada anak. Populasi adalah semua jurnal penelitian tentang assessment dan manajemen trauma pada anak. Sampel adalah jurnal hasil penelitian tentang assessment dan manajemen trauma pada anak di instalasi gawat darurat yang memenuhi kriteria inklusi. Kriteria inklusi sampel dalam penelitian ini meliputi: 1). merupakan penelitian dengan desain retrospective, literatur review, 2). responden dalam jurnal penelitian adalah Pasien anak dengan trauma, 3). hal yang diteliti tentang assessment dan manajemen trauma pada anak, 4). hasil penelitian yang dipublikasi dalam rentang tahun 2000-2015.

Sumber literatur review dari text book dan artikel elektronik seperti ScienceDirect; World Health Organisation, Google Scholar dan PubMed dengan kriteria textbook dan artikel yang dipublikasi selama periode 2000-2015 dengan menggunakan kata kunci" assessment, management; paediatric trauma". Hasil penelusuran didapatkan 15 artikel tentang assessment dan manajemen trauma pada anak, hanya 7 artikel yang memenuhi kriteria inklusi. 


\section{Hasil}

Assessment dan manajemen trauma pada anak harus dilakukan dengan terorganisasi, mendalam dan tidak terpisah-pisah (Abantanga et al, 2010). Assessment dan manajemen trauma pada anak yang benar adalah sebagai berikut:

\section{Primary Assessment dan Resusitasi}

Merupakan pengkajian untuk mengidentifikasi life-threatening injuries yang membahayakan oksigenasi dan sirkulasi. Prinsip utama dalam primary assessment adalah evaluasi $\mathrm{ABCDE}$ dan melakukan manajemen yang efektif setiap ditemukan masalah yang mengancam nyawa (Abantanga et al, 2010). Menurut Orlando Health Education \& Development (2011), Murray \& Cordle (2015) dan Maryniak (2015) berikut adalah uraian dalam primary assessment:

a. Airway dan stabilisasi tulang belakang

Merupakan prioritas utama dalam primary assessment dengan melihat patensi, potensial obstruksi jalan nafas dan melakukan stabilisasi tulang belakang dengan cervical collar. Dalam airway manajemen tindakan intervensi yang diberikan antara lain:

1) Menggunakan manuver jaw thrust untuk membuka jalan nafas. Merupakan implikasi dari anatomi lidah anak yang besar dibandingkan rongga mulut

2) Mempertahankan imobilisasi spinal terutama jika terindikasi trauma spinal
3) Lakukan suction pada rongga mulut dengan Yankauer suction (tidak boleh merangsang reflek gag)

4) Apabila airway paten tidak bisa dipertahankan maka pasang oropharingeal airway. Pemasangan nasofaringeal tidak direkomendasikan karena potensial perdarahan, infeksi (sinusitis) dan peningkatan TIK

5) Lakukan pemasangan intubasi dengan rapid sequence intubasi medication (indikasi: control airway yang lama, membutuhkan ventilasi adekuat, GCS $<9$ (mengontrol hiperventilasi) dan kegagalan pernafasan).

6) Apabila terjadi stridor atau sianosis maka berikan $\mathrm{O}_{2} 100 \%$, pasang intubasi $\left(\mathrm{PO}_{2}\right.$ $<50 \mathrm{mmHg}$ atau $\mathrm{PCO}_{2}>50 \mathrm{mmHg}$ ) dan lakukan needle cricotomy (bila intubasi tidak memungkinkan sama sekali)

7) Other Consideration: Monitoring $\mathrm{ETCO}_{2}$, pasang NGT untuk mencegah distensi dan dan apabila terjadi trauma laring/trakea langsung lakukan cricothyrotomy atau emergency tracheostomy.

b. Breathing dan ventilasi

Dilakukan setelah airway paten/aman. Assessment termasuk RR, kedalaman pernafasan, auskultasi bunyi nafas dan melihat pergerakan dinding dada. $\mathrm{O} 2$ harus diberikan pada semua pasien trauma melalui nasal kanul atau face mask jika tidak terdapat 
tanda dan gejala perburukan pernafasan. Pulse oximetry dapat digunakan untuk mempertahankan $\mathrm{O}_{2}>96 \%$. Untuk pasien dengan apnea dan bradypnea maka rescue breathing dapat diberikan dengan Bag-valve mask dengan $\mathrm{O}_{2}$ 100\%. Sedangkan untuk intubasi dapat dilakukan jika ventilasi tidak adekuat dengan bag-valve mask, kegagalan pernafasan dan syok yang tidak responsif dengan volume resuscitation. Berikut adalah intervensi yang dilakukan berdasarkan hasil assessment:

1) RR meningkat (mengindikasikan kegagalan pernapasan) dapat dilakukan intubasi, jika syok diberi resusitasi cairan, nyeri diberi analgesik

2) Pergerakan dinding dada (paradoksal) menandakan flail chest sehingga memerlukan $\mathrm{O}_{2} 100 \%$ NRBM/intubasi

3) Kelainan bunyi nafas mengindikasikan adanya pneumothorax (letakkan chest tube), hemothorax (lakukan pemasangan drainage) dan open pneumothorax (pemasangan tube thoracostomy)

4) Adanya deviasi trakea mengindikasikan tension pneumothorax dapat dipasang needle decompress/thoracocentesis

\section{c. Circulation dan kontrol perdarahan}

Pada pasien anak tidak selalu takikardia menunjukkan tanda awal terjadinya syok. Nyeri dan kecemasan pada pasien anak juga menunjukkan gejala takikardia oleh karena itu diagnosa syok dapat terjadi jika pasien menunjukkan gejala takikardia, perubahan status mental, penurunan PP, akral dingin, penurunan output urine, CRT $>2$ detik, hipotermia dan hipotensi. Untuk itu assessment terpenting dalam sirkulasi ini adalah HR, BP, bandingkan nadi apikal dan brankial, temperatur kulit, warna kulit, CRT dan identifikasi tempat perdarahan. Sedangkan penanganan sirkulasi trauma anak adalah

1) Prioritas utamanya adalah mengkonfirmasi ada atau tidak nadi, Jika nadi tidak ada maka mulai dengan CPR, jika nadi <60x/menit lakukan resusitasi sesuai guidelines AHA Pediatric Advanced Life Support

2) Prioritas selanjutnya adalah external hemorrhages, yang dapat dilakukan tindakan penekanan langsung dan ditinggikan

3) Melakukan pemasangan IV. Pasang kateter IV jarum besar 2 line pada ekstremitas atas, jika tidak berhasil dilakukan pemasangan intraosseous atau vena sentral. Berikan RL atau $\mathrm{NaCl}$ 0,9\%, $20 \mathrm{~mL} / \mathrm{kg}$ dan diulang sebanyak 3 kali (hipovolemia berat). Bila tidak ada perbaikan dalam 30-60 menit dapat diberikan PRC 10 ml/kgBB/WB 20 ml/kg BB sampai kondisi hemodinamik pasien stabil. 
4) Selama resusitasi pasien harus terpasang kateter untuk evaluasi produksi urine (usia<1 tahun produksi urine 2 $\mathrm{ml} / \mathrm{kgBB} / \mathrm{jam}$, usia>1 tahun produksi urine $1 \mathrm{ml} / \mathrm{KgBB} / \mathrm{jam})$

\section{d. Disability Assessment (Pemeriksaan} neurologis lengkap)

Fokus assessmentnya adalah melihat tingkat kesadaran pasien dengan sistem AVPU dan modifikasi pediatric GCS, respon pupil dan kesimetrisan serta ukurannya. Untuk treatment dan intervensinya adalah

1) Stabilisasi tulang belakang atau posisikan kepala netral, GCS $<9$ merupakan indikasi dilakukan intubasi (RSI) dan beri $\mathrm{O}_{2}$ $100 \%$

2) Jika terjadi AMS dengan indikasi trauma kepala yang dibuktikan hasil CT-scan segera konsultasikan ke neurosurgical, Apabila AMS disertai tanda herniasi berikan manitol 0,25-0,5 $\mathrm{g} / \mathrm{kg}$ IV dan pertahankan $\mathrm{PCO}_{2} 30-35 \mathrm{mmHg}$

3) Pertahankan CPP minimal $50 \mathrm{mmHg}$ dan kaji tanda spinal injury termasuk kegagalan pernafasan dan bulbocavernosus reflex.

e. Exposure dan Pemeriksaan lengkap

Dilakukan dengan membuka baju anak untuk mengidentifikasi trauma yang mungkin tidak terlihat dan tetap mempertahankan kondisi pasien normotermia. Pada fase ini juga merupakan saat yang tepat untuk dilakukan pemeriksaan imaging dan tes diagnostik lain, intervensi suportif (reduksi dan splinting) dan pemberian pengobatan (analgesik, vaksin tetanus serta antibiotik)

\section{Secondary Assessment}

Merupakan tindakan yang dilakukan setelah pasien dalam kondisi stabil untuk mengidentifikasi cedera yang tidak mengancam nyawa (Abantanga et al, 2010). Pemeriksaan ini lebih detail mencangkup:

\section{a. Full set of vital sign/family presence}

Melakukan pemeriksaan vital sign yang diulangi sampai kondisi pasien stabil, pemasangan monitor $\mathrm{BP}$, pemasangan pulse oximetry, pemasangan kateter urine dan pemasangan NGT (sebagai dekompresi untuk mencegah distensi abdomen akibat adekuat ventilasi) (Orlando Health, Education \& Development, 2011)

\section{b. Give comfort}

Pasien anak dengan trauma selalu disertai nyeri. Untuk itu harus dilakukan pengkajian dan manajemen nyeri yang tepat. Manajemen nyeri yang biasa diberikan adalah melakukan anestesi lokal di area cedera, kombinasi pemberian analgesik per oral maupun intravena, pemasangan splinting, kompres es, posisi, teknik relaksasi atau sentuhan (McFadyen et al, 2012) 


\section{c. History dan Head-to-toe assessment}

History mencangkup mnemonic SAMPLE dan mekanisme cedera pasien (Abantanga et al, 2010). Selain itu juga dilakukan pemeriksaan head-to-toe secara detail dengan inspeksi, palpasi dan auskultasi. Tindakan yang biasa dilakukan adalah melakukan perawatan luka, perawatan fraktur dan pemeriksaan diagnostik yang lebih detail pada bagian tubuh yang cedera (Hammond \& Zimmermann, 2013).

\section{d. Inspect posterior surfaces}

Melihat area tulang belakang dengan melakukan log roll untuk inspeksi, palpasi adanya nyeri, tenderness dan instability tulang belakang (McFadyen et al, 2012)

\section{Re-evaluasi dan Monitoring}

Dilakukan untuk mengevaluasi perubahan kondisi pasien. Biasanya re-evaluasi dilakukan setiap 15 menit pada pasien kondisi stabil dan setiap 5 menit pada pasien kondisi tidak stabil (Abantanga et al, 2010)

\section{Definitive Care}

Merupakan tindakan perawatan untuk non-life-threatening injury yang ditemukan selama secondary assessment. Tindakan ini dapat berupa mengirim pasien pada unit trauma lain (seperti pasien luka bakar), transfer ke ruang operasi atau bila mungkin dipindahkan ke ICU (Orlando Health, Education \& Development, 2011; Abantanga et al, 2010).

\section{Pembahasan}

Pada prinsipnya guidelines ATLS manajemen trauma pada anak sama dengan orang dewasa, hanya terdapat beberapa perbedaan anatomi dan fisiologi seperti airway anatomy, perbedaan rasio oxygen consumption, respon terhadap kehilangan darah, thermoregulasi dan ukuran tubuh anak. Perbedaan tersebut menyebabkan anak rentan jalan nafasnya tersumbat, mudah mengalami kegagalan pernafasan, mudah terjadi syok hipovolemik, hipotermia, resiko terjadi trauma multiple, trauma kepala berat dan trauma tumpul abdomen. Selain anatomi dan fisiologi, respon psikologis anak mempunyai pengaruh besar sekali dalam komplikasi psikologis sampai bisa berakibat kematian pada anak bila tidak diperhatikan dengan seksama. Respon psikologis yang mempengaruhi komplikasi respon fisiologis adalah pengeluaran katekolamin yang meningkatkan tekanan darah dan denyut nadi; penurunan output urin; koagulasi darah, meningkat kehilangan panas dan peningkatan kadar glukosa darah. Hal-hal spesifik tersebut akan berimplikasi terhadap manajemen atau penanganan trauma pada anak (Fisher, 2015; Harrois et al, 2013; Dennies, 2005).

Manajemen trauma pada anak dimulai dari primary assessment yaitu dengan pendekatan $\mathrm{ABC}$ resusitasi. Jika anak terjadi trauma segera amankan jalan nafas dengan 
teknik jaw thrust. Teknik ini merupakan teknik yang paling tepat untuk membuka jalan nafas pada anak berkaitan dengan anatomi tubuh anak dan membantu mengangkat lidah dan jalan nafas terbuka. Sedangkan pasien tidak sadar dan reflek gag tidak ada bisa menggunakan oropharyngeal airway. Penggunaan nasofaringeal tidak direkomendasikan karena dapat menyebabkan terjadinya komplikasi seperti menyebabkan perdarahan di acute angle of the posterior pharynx dan terjadi infeksi atau sinusitis. Jika tidak memungkinkan dengan oropharingeal maka dapat dilakukan intubasi dengan syarat: pertama, pasien tidak sadar dengan $G C S<9$. Kedua, pasien membutuhkan ventilasi yang adekuat. Ketiga, pasien mengalami kegagalan pernafasan atau hipoxemia. Keempat, pasien mengalami syok resisten yang tidak berespon dengan pemberian cairan (Murray\&Cordle, 2015; Maryniak, 2015).

Intubasi pada pasien anak ini termasuk special consideration karena menyebabkan bradikardia sehingga dapat diberi atropin atau glycopyrrolate sebelumnya. Selain itu beberapa hal yang harus dilakukan saat melakukan intubasi pada anak adalah berikan oksigen $100 \%$ terlebih dahulu, pertahankan tulang spinal dalam keadaan netral atau sejajar dan selalu monitor heart rate dan saturasi oksigen pasien selama proses intubasi, perhatikan ukuran intubasi yang digunakan (3,0-7,0 mm). Setelah intubasi selesai juga diperlukan pemeriksaan ketepatan menempatkan tube ETT, ETT terpasang dengan tepat jika pergerakan dinding dada simetris, suara nafas sama antara kiri dan kanan, ada pengembunan pada endotracheal tube, jika menggunakan CO2 detektor akan terlihat warna kuning (Maryniak, 2015).

Apabila airway aman maka segera lakukan assessment dan tindakan emergency terkait gangguan pada breathing. Pada saat assessment di breathing ini maka perhatikan adanya pernafasan paradoksal yang mengindikasikan kegagalan pernafasan. (diberikan oksigen 100\% melalui BVM). Akan tetapi dalam pemberian oksigen melalui $\mathrm{Bag}$ valve mask pada anak juga harus diperhatikan volume dan kecepatan (Volume yang berlebihan atau pemberian yang terlalu cepat akan menyebabkan kelebihan volume yang dapat meningkatkan distensi abdomen dan kegagalan ventilasi yang memicu aspirasi pada anak dan menyebabkan kematian). Oleh karena itu pasien anak harus terpasang nasogastric atau orogastric tube setelah pemasangan intubasi atau pemakaian Bag valve mask. Pada breathing ini juga yang perlu diperhatikan adalah ditemukannya tanda-tanda life-threatening thorax injury seperti pneumothorax, hemothorax, tension pneumothorax dan pericardial tamponade yang harus dilakukan intervensi dengan segera. Apabila ditemukan tanda signifikan pneumothorax maka segera 
lakukan pemasangan chest tube, jika terdapat tanda hemothorax segera transfer ke ruang operasi untuk segera dilakukan pemasangan drainage (jika drainage $>15 \mathrm{ml} / \mathrm{kg}$ ), ada tanda open pneumothorax maka segera lakukan tindakan pemasangan tube thoracostomy dan kemudian sisi yang ditusuk ditutup dengan occlusive dressing dan apabila ada tanda tension pneumothorax yaitu ada deviasi trakea maka segera lakukan needle decompresi di intercostal kedua mid clavicular line. Setelah tindakan emergency dilakukan segera evaluasi pernafasan anak. Ventilasi adekuat jika airway paten dan pertukaran gas baik (Murray \& Cordle, 2015; Maryniak, 2015).

Setelah itu dilanjutkan pada assessment circulation dan hentikan perdarahan. Pada anak sangat rentan terjadi syok hipovolemik sehingga harus diwaspadai jika terdapat tanda takikardia. Jika takikardia segera konfirmasi dengan tandatanda syok yang lain seperti perubahan status mental, penurunan pulse pressure, perburukan pernafasan, perfusi di kulit terutama di ekstremitas dingin, penurunan urine output, perlambatan capillary refil time, hipotermia dan hipotensi. Adanya hipotensi menunjukkan bahwa kehilangan volume darah sirkulasi $>45 \%$ dengan perkiraan $80 \mathrm{ml}$ per $\mathrm{kg}$ BB. Jika ditemukan tanda gejala syok tersebut maka harus segera dilakukan manajemen resusitasi cairan. Lakukan pemasangan infus 2 line sekaligus pada ekstremitas bagian atas. Apabila tidak berhasil dengan intravena maka pada anak usia kurang dari 6 tahun dapat diakses melalui intraosseous (IO). Apabila infus telah terpasang segera lakukan resusitasi cairan dengan normal saline atau ringer laktat dengan pemberian dalam keadaan hangat (warm isotonic crystalloid) untuk mencegah terjadinya hipotermia. Untuk pemberian awal cairan adalah $20 \mathrm{ml}$ per kg BB IV bolus dengan goal hemodinamik pasien menjadi stabil dan terjadi perbaikan sirkulasi. Apabila dalam 30-60 menit tidak terjadi perubahan status hemodinamik dapat diberikan ulang sampai 3 kali dengan total pemberian 40-60ml per $\mathrm{kg}$ BB. Pada pasien syok hemoragik jika tidak berespon terhadap resusitasi cairan maka dapat diberikan produk darah yaitu packed red blood cell (PRC) dosis pemberiannya adalah $10 \mathrm{mll}$ per $\mathrm{kg} \mathrm{BB}$ atau Whole blood (WB) dosis pemberian adalah 20 $\mathrm{ml}$ per $\mathrm{kgBB}$ (Shweer \& Lynn, 2008; Murray\&Cordle, 2015; Abantanga et al, 2010).

Setelah ABC resusitasi terlampaui maka selanjutnya pemeriksaan status mental yang sangat penting untuk mengevaluasi keberhasilan. Jika pasien mempunyai skor GCS 6-8 ini mengindikasikan adanya hipotensi (SDP $<90 \mathrm{mmHg}$ ) dimana potensial atau resiko kematian akan meningkat. Jika pasien mempunyai GCS skor $\leq 8$ mengindikasikan pasien memerlukan tindakan intubasi terutama pada pasien dengan cedera kepala. Apabila dalam pemeriksaan status mental pasien 
menunjukkan traumatic brain injury dapat diberikan phenytoin (10-20 mg per $\mathrm{kgBB}$ ), diazepam $(0,25 \mathrm{mg}$ per $\mathrm{kg} \quad \mathrm{bb})$ atau phenobarbital (2-3mg per kg BB). Jika pasien menunjukkan gejala peningkatan TIK dan hipovolemia dengan hemodinamik tidak stabil dapat diberikan manitol dan furosemid (Abantanga et al, 2010)

Dalam manajemen trauma anak selain initial resusitasi $\mathrm{ABC}$ yang terpenting juga adalah mencegah hipotermia, manajemen nyeri dan memberikan support emosional yang adekuat bagi anak dan keluarga (Sundberg et al, 2011). Pencegahan hipotermi dengan pertahankan suhu pediatric trauma room $>80^{\circ} \mathrm{F}$, ganti baju yang basah dan selimuti pasien, minimal exposure, warmed humidifikasi $\mathrm{O}_{2}$, hangatkan cairan dan darah serta jika memungkinkan gunakan sumber radiasi atau konveksi (McFadyen, 2012; Murray\&Cordle, 2015).

Manajemen selanjutnya adalah terhadap nyeri. Nyeri ini bermanifestasi pada fisiologi, biochemical dan perilaku yang berhubungan dengan hemodynamic instability dan penyembuhan luka yang terhambat. Selain itu nyeri juga berkaitan dengan hipoventilasi yang menyebabkan terjadi hipoxia (menjelaskan efek opioid untuk manajemen nyeri yang dapat meningkatkan fungsi pernafasan karena efek paradoxical). Untuk itu diperlukan manajemen nyeri pada anak yang dapat dilakukan secara farmakologi dan nonfarmakologi. Manajemen farmakologi yang sering diberikan pada anak adalah analgesik dan manajemen non farmakologi seperti distraksi, relaksasi, hipnotis dan dukungan keluarga (Greenwald, 2010). (Anantha et al, 2014).

Support emosional terhadap anak dan keluarga juga merupakan hal yang penting untuk dilakukan untuk menurunkan kecemasan dan ketakutan yang mungkin dialami oleh anak. (Martin, 2010, Greenwald, 2010; Orlando Health, Education \& Development, 2011). Sehingga dari semua tindakan diatas pada dasarnya fokus dalam penanganan pasien anak adalah pada aspek fisik dan aspek psikologis untuk menurunkan trauma pada anak (Alisic et al, 2014)

\section{Kesimpulan}

Trauma merupakan penyebab kematian utama pada anak. Untuk itu diperlukan assessment dan manajemen yang tepat untuk meminimalkan kematian. Assessment dan manajemen trauma pada anak pada prinsipnya sama dengan orang dewasa, akan tetapi terdapat perbedaan yang signifikan pada anatomi, fisiologi dan respon psikologis anak yang berimplikasi pada manajemen trauma pada anak. Dalam manajemen trauma pada anak kunci terpenting adalah primary assessment untuk mengidentifikasi life-threatening injury yang membahayakan oksigenasi dan sirkulasi 
dengan prioritas utama adalah kontrol airway, perbaiki breathing dan manajemen resusitasi cairan. Selain itu prioritas penanganan pasien trauma pada anak adalah pencegahan hipotermia, manajemen nyeri dan memberikan dukungan emosional pada anak maupun keluarga.

\section{Referensi}

Abantanga, et al. (2010). Initial Assessment and Resuscitation of the Trauma Patient. Rosen's Emergency Medicine. Philadelphia, Saunder.

Alisic, E., Conroy, R., Magyar, J., Babl, F.E., Meaghan, L., Donnell, L.O (2014). Psychosocial care for seriously injured children and their families: A qualitative study among Emergency Department nurses and physicians. Injury, Int. J. Care Injured 45, 1452-1458. DOI: http://dx.doi.org/10.1016/j.injury.2014.02 .015 . Elsevier.

American Academy of Pediatric. (2012). American Academy of Pediatrics And Pediatric OrthopaedicSociety Of North America. Pediatrics 2008;121;849. DOI: 10.1542/peds.2008-0094

http://pediatrics.aappublications.org/cont ent/121/4/849.full.html

Allen, C.J., Teisch, L.F., Meizoso, J.P., Ray, J.J., Schulman, C.L., Namias, N., Sola, J.E., Proctor, K.G (2015). "Prehospital care and transportation of pediatric trauma patients." journal of surgical research: 17.DOI: 10.1016/j.jss.2015.03.005.

American Academy of Pediatric. (2012). American Academy of Pediatrics And Pediatric OrthopaedicSociety Of North America. Pediatrics 2008;121;849DOI: 10.1542/peds.2008-0094 http://pediatrics.aappublications.org/cont ent/121/4/849.full.html

Consideration in Pediatric Trauma. (2015, Nov 4) Retrieved August 10, 2017, from http: //emedicine.medscape.com/article/43503 1-overview

Anantha, R.M., Stewart, T.C., Rajagopalan, A., Walsh, J., Merritt, N.H (2014). Analgesia in the management of pediatric and adolescent trauma during the resuscitative phase: The role of the pediatric trauma center. Injury, Int. J. Care Injured, 45: 845-849.

Bakes, K., and G. Sharieff (2013). Pediatric Trauma. Philadelphia, Elsevier Saunders

Curran, T., and Y. Hwan Chun (2014). Blunt Abdominal Trauma in Pediatric Pediatric Trauma Care A Clinical Reference for physicians and nurses caring for the acutely injured child. Atalanta, AHC Media. 2: 27.

Dennis W. Vane, Martin S. Keller, Kenneth H. Sartorelli and Alex P. Miceli (2005). Pediatric Trauma: Current Concepts and 
Treatments. Journal of Intensive Care Medicine. 17 (5); 230-249.

Dewi, dkk. (2008). Karakteristik Klinis Trauma

Kepala pada Anak di RS Dr. Cipto Mangunkusumo Jakarta.Sari Pediatri, 2008; 9(5):354-8

Fisher, R.M (2015). "Paediatric trauma." SURGERY FOR MAJOR INCIDENTS 33(9): 437-441.

Geibel, J. (2014). Blunt Abdominal Trauma, Medscape

Greenwald, M (2010). "Analgesia for the Pediatric Trauma Patient: Primum Non Nocere?" Pediatric journal, 11(1): 20-40.

Hammond, B., and P. Zimmermann (2013).

Sheehy's Manual of Emergency Care. Missouri, Mosby Elsevier

Harrois, A., Hamada, A., Laplace, C., Duranteau, J., Vigue (2013). "The initial management of severe trauma patients at hospital admission." Annales Franc saises d'Anesthe' sie et de Re'animation 32: 483-491. DOI: http://dx.doi.org/10.1016/j.annfar.2013.0 7.006

Life Support Training Centre, (2008). Basic Trauma Life Support (Pertolongan Hidup Dasar Trauma). Malang: Malang Trauma Services IRD RSU dr. Saiful Anwar Martin (2010). Family Presence During Resuscitation And Invasive Procedures.
American Association Critical-Care Nurses

Maryniak, K (2014). "Pediatric Trauma: Assessment and Management."

McFadyen, J.G., Ramaiah, R., \& Bhananker, S.M. (2012). Initial assessment and management of pediatric trauma patients. International Journal of Critical Illness and Injury Science, 2(3), 121-127.

Murray and Cordle (2015). Pediatric Trauma. Text Book of Critical Care. Philadelphia, Saunders.

Oman, Kathleen S. (2008). Panduan Belajar Emergensi, terjemahan. Jakarta: EGC

Orlando Health Education \& Development (2011). "Overview of Pediatric Trauma." Orlando Health Education \& Development

Paden, M., Oyegbite, K., Ozanne-Smith, J., Hyder, A.A., Branche, C., Rahman, F., Rivara, F., Bartolomeis, K (2010). World Report on Child Injury Prevention. Wounds and injuries-prevention and control accident prevention Child Welfare. Switzerland, World Health Organization.

Prentiss et al (2007). Emergency Management of The Pediatric Patient: Cases, Algorithms, Evidence. Philadelphia: Lippincott Williams \& Wilkins. 
Riset Kesehatan Dasar. (2013). Badan Penelitian dan Pengembangan Kesehatan Kementerian Kesehatan RI

Riset Kesehatan Dasar. (2013). Badan Penelitian dan Pengembangan Kesehatan Kementerian Kesehatan RI

Russel, R., Halcomb, E., Caldwell, E., Sugrue, M. Differences in Mortality Predictions Between Injury Severity Score Triplet: A Significant Flaw. J.Trauma. 56 (6):13214

Schweer and Lynn (2008). Pediatric Trauma Resuscitation: Initial Fluid Management. Journal of Infusion Nursing. 31(2):104111.

Schvartsman, C., Carrera, R., Abramovici, S (2005). "Initial assessment and transportation of an injured child." Jornal de Pediatria, 81(5): 223-229. doi: 10.2223/JPED.1411.

Sundberg, J., Estrada, C., Jenkins, C., Ray, J \& Abramo, T (2011). Hypothermia is associated with poor outcome in pediatric trauma patients. American Journal of Emergency Medicine 29, 1019-1022. doi:10.1016/j.ajem.2010.06.002. Elsevier Inc. 